\title{
OF MONSTERS AND MEN: THE AESTHETICS OF THE ALT-RIGHT
}

Thari Jungen

Graduate School "Performing Citizenship," Hamburg

\section{/// 1. Introduction}

On 22 February 2017, Chelsea Clinton tweeted a picture of a magazine cover with the following headline: "Hillary Clinton Adopts Alien Baby." The picture is the cover from a twenty-six-year-old issue of the tabloid magazine Weekly World News (see Fig. 1). Along with the tweet, Clinton

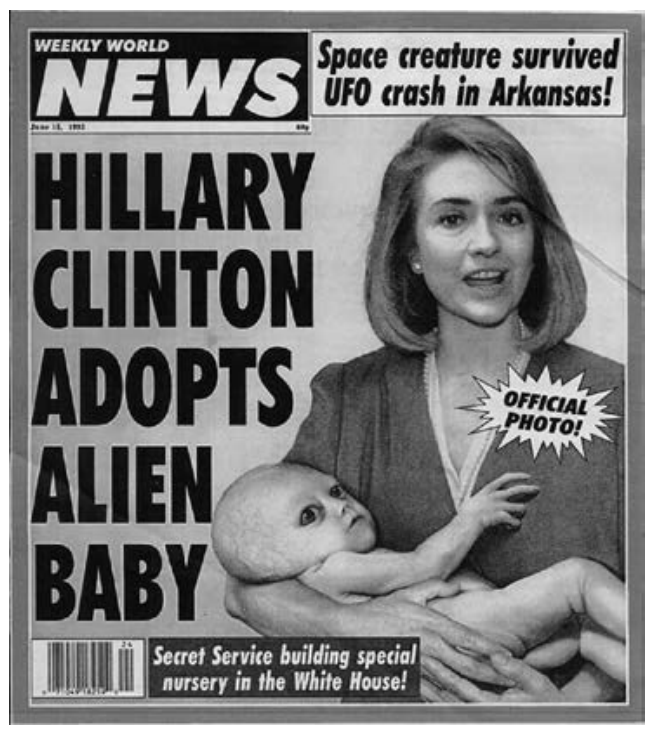

Figure 1. Cover of Weekly World Nems, issue of 15 June 1993. Original available online at "Five Classic Weekly World News Covers," Weekly World News, 2.10.2008, https:// weeklyworldnews.com/headlines/3075/five-classic-weekly-world-news-covers/, accessed 30.11.2019. Reproduced with permission from Weekly World News 
derided the harmful disinformation and bullying tactics used to attack her mother: "I'd forgotten about my alien sibling from the early 90s. Oh the good old days when \#fakenews was about aliens..." (Clinton 2017).

In autumn 2016, a few months before, the same collage had been widely shared on social media and blogs such as uspolitics.com by A., a fake-news producer from Veles, Macedonia. ${ }^{1}$ The collage shows the former presidential candidate Hillary Clinton gently smiling while holding an "alien baby" in her arms. On Facebook alone, the distribution counted more than 5,000 clicks.

In December 2016, the small North Macedonian town of Veles became popular due to international reports on its fake-news producers and large amount of fake-news websites. Two months later, in February, the artistic collective Institute for Falsification (IFF) travelled to Veles. ${ }^{2}$ As a member of IFF, I interviewed several fake-news producers and collected video and audio material to explore their motivations, the production of fakes, and the distribution of fake news on social media. The investigation is part of my artistic research and was presented in the video installation Show Me Your Agenda. ${ }^{3}$ The video installation displayed the newly built, neoclassical city centre of Skopje, a result of the national branding campaign entitled Skopje 2014, which flaunted images of bags decorated with the labels of "Channel" and "Guci"; the installation also featured Tom Kummer's fictitious interview with Ivana Trump, citing Andy Warhol's biography. ${ }^{4}$ On the one hand, these manifold forms of deception have their lasting effects on society, science, and arts. On the other hand, it can be seen from the effects that a universalistic mimicry thesis, which coined, for instance, the term "post-factual age," is barely enlightening for the purpose of a more precise differentiation between the particular forms and shapes

\footnotetext{
${ }^{1}$ In this article, the fake-news producer A. is anonymised. If texts with existing attributions are cited, the names are withheld.

${ }^{2}$ For more information on the Institute for Falsification (in German Institut für Falsifikate), of which this chapter's author is a member, see www.institutfuerfalsifikate.net (accessed 30.11.2020). In a series of diverse artistic research settings, the IFF investigates practices of faking and hoaxing in cooperation with everyday experts and (non-)citizens. It does not focus on spectacular cases of deception but on examining everyday practices in relation to prevailing discourses, relations of representation, and practices of governance, which appear to be constitutive for producing deception. 3 In May 2017, the results of the artistic research project were presented in a multimedia installation entitled Show Me Your Agenda in Hamburg at K3, Kampnagel. The work was produced within the graduate programme "Performing Citizenship."

${ }_{4}^{4}$ Around the year 2000, former journalist Tom Kummer launched several fake interviews in the German newspaper Süddeutsche Zeitung. After the fakes' exposure, he claimed that he utilised a postmodern technique. Instead of meeting his interview partners, such as Ivana Trump, he appropriated existing statements, such as in this case from a biography of Andy Warhol, and put them in the mouth of the alleged interview partners.
} 
of deception. In the following, I intend to use the results of our research to locate the Clinton hoax more precisely within the framework of the ongoing fake-news debate. My research perspective thereby involves a political as well as aesthetic approach.

By focusing on the Hillary Clinton hoax, I understand that this form of collage is a significant political-aesthetic phenomenon and that it is commonly used in order to distribute false information online. Its aesthetic characteristics refer to the imagery of cartoons; they fall back on wellknown symbols from conspiracy theories and take a humorous approach. Upon closer inspection, I find that the fake-news producers are working with activist techniques and the aesthetics of the so-called guerrilla communication movement, by using images that refer to popular political symbols of the twentieth century.

Despite their popularity, fake-news collages like the one above are only of marginal interest to scholarly discourse. Based on an emphatic relation between truth and democracy, fake news is broadly discussed as an offence to democracy. Therefore, it could be argued that the scholarly fake-news discourse usually needs to concentrate on more serious issues than alien adoptions. As for the humanities, the discussion of fake news is mainly shaped from a political and philosophical perspective, by discussing a new positivist ideal of separating truth from attitude (Arendt 1972; Flatscher \& Seitz 2018; van Dyk 2017). ${ }^{5}$ Until the 1980s, in the arts and in journalism, hoaxes were commonly understood as the projections of the stories of swindlers or as fantasies of subversion when apprehended as emancipative practices of critique. Today, however, the fakes of right-wing organisations such as the Identitarian Movement are recognized as politically informed techniques (compare Ebner 2019: 46). Satirical, epigonal fakes, such as the Clinton photomontage, which is recognisable as a common form of online practice, are usually dismissed as "bullshit" (in accord with Harry Frankfurt's (2005) definition).

As a result of this theoretical gap, I propose to analyse the strategic function of the Clinton photomontage, since it is an example of a specific variety of fake news in social media. I assume that collages like the Clinton hoax have maintained a strategic role in the fake-news debate. To investigate the role of fake news more properly, a deeper understanding of the knowledge they convey is needed. Thus, I will take a closer look at the tactics of appropriation and humour in the image contents of the Clinton

\footnotetext{
${ }^{5}$ See Bernhard Kleeberg's discussion of "reactionary epistemologies" in the paper "Post PostTruth: Epistemologies of Disintegration and the Praxeology of Truth" in this volume.
} 
photomontage. In doing so, I propose a reference to Michel Foucault's notion of the dispositive as an apparatus. According to Foucault, the apparatus is a "sort of formation which has a major strategic function at a given historical moment [namely] that of responding to an urgent need" (Foucault 1980: 194ff.). Since this formation results, amongst other things, in the production and distribution of fakes, it is crucial to understand the fakes as a part of the dispositive of social media. Subsequent to a detailed analysis of the Clinton photomontage, it is my aim to characterise the role of images in the production of fake news. Therefore, it is first necessary to give a more accurate definition of the phenomena of appropriation and hoax in order to understand the diverse motives behind them and their multiple discursive effects.

\subsection{The Aesthetic Appropriation of Signs as a Postmodern Subversive Strategy}

In everyday language, "to appropriate something" means to take possession of something, even if one is not allowed to. Questions of purpose, ownership, and authenticity become obvious when appropriations are acknowledged as practices. I suggest understanding fake news as appropriations that adopt the form and content of media. Hoaxes, such as the one mentioned above, can be understood as materialised lies that fall back on established imagery and can be easily decoded as deceptions. Although they expose their epigonality openly, these fakes can get overwhelming attention and thousands of clicks. What makes them interesting for an investigation is, therefore, neither an ingenious nor an interesting process of deception, but rather their previously unknown significance within the fake-news discourse. Consequently, I claim that image-text combinations such as the Clinton photomontage, which initially seem to be meaningless satires, produce narrative, materialist, and technical levels of aesthetic and political effects that must be analysed by concentrating on their medium, performance, and symbolism.

In order to follow this analytic framework, it is necessary to first explore why the appropriation and reinterpretation of social signs can be understood as a subversive practice. Therefore, a brief digression into its specific postmodern frame of reference and culture is unavoidable. This notion goes back to the 1960s, when the situationist Guy Debord (amongst others) proposed a political power shift through the practice of decoding signs. In his book Society of Spectacle, Debord (1984) shows that society 
develops through symbolic contexts of action, whose reality (and thus political aspect) disappears behind an illusory world of advertising, cliché, and propaganda, and therefore can only be experienced as representation. Debord argues that only decoding signs would help "to infiltrate the social body" and to "subvert" it from the inside. His theoretical idea inspired a whole repertoire of practices of appropriation and reinterpretation within the visual field. The Situationist International group (with its most famous member, Debord) was mostly influenced by the Dadaist photomontages of, for instance, John Heartfield and George Grosz, who visualised their political-artistic struggle against the mechanisms and logics of capitalist alienation. ${ }^{6}$ Sticking to Heartfield and Grosz's methods, the Situationist International reacts to social and political crises with an aesthetic method called détournement (compare Debord 2008: 21), which involves the reinterpretation of existing signs: "It's about getting a truth, but using the same sort of weapons of fiction that the people in power use all the time" (Willmann 2004). During the following decades, détournement became a popular aesthetic strategy that alienates existing images, symbols, and language, for the effect of seizing, distorting, or destroying predominant codes and signs (see Certeau 2014). For this purpose, tactics of everyday life are used as alienation and over-identification (ibid.).

Since the 1980s, guerrilla communication collectives such as the German a.f.r.i.k.a. Gruppe have been living up to the traditions of the Situationist International when they stage multiple crises in the public sphere for the purpose of de-identification. According to the manual of guerrilla communication, artistic quality, as measured by standards of art history, is more important than usability as a means of subversive political practice (compare Blissett \& Brünzel 2001).

The purpose of guerrilla communication, therefore, is to disrupt the reproduction of power relations and to break the euphemisms conveyed by advertisement and newspaper articles. According to Isabelle Graw (2004: 300 ), until the late 1980s visual appropriation practices in the arts were applied with self-affirmative efficacy to destroy critical discourse. As Fredric Jameson (1984: 113) states, reinterpretation, as well as the use of references, became an essential characteristic of postmodernism.

\footnotetext{
${ }^{6}$ As Vera Chiquet (2018: 15ff.) explains, Heartfield and Grosz acknowledged themselves to be fitters or engineers, as was also mirrored in their cooperation, which they called "Heartfield Grosz Konzern." Often dressed in a blue suit, Heartfield, who looked more like a mechanic (a Monteur in German), depicted the image of an anti-artist. It is fair to say that Heartfield's way of dressing inspired Grosz to call the practice of combining photo snippets "montaging."
} 


\subsection{Aesthetic Appropriations as Powerful Practices of the Alt-Right}

Used as "tools of crisis," this repertoire of aesthetic practices, which has been the established imagery of the "political" since the French Revolution at the latest, can now also be found in the aesthetics of the alt-right (compare Schober 2009: 37). According to Anna Schober (2005: 5-6), practices such as montage, humour, and spectacle aim to problematise the daily trouble of being-in-the-world. As practical commentaries, montages intervene in the predominant order of society. According to Jean-Luc Nancy (2010), these forms of aesthetics invoke the staging of crises to rearrange and restructure their meaning afterwards. In contrast to the alt-right movement, the artistic avant-garde defined those acts, cultural productions, and perspectives as political forms that use a mutual exchange to question the structural principles of society (compare Schober 2005: 5-6). According to this definition of the political, images are understood as the central element of socialisation. Beyond such activist contexts, deconstructivist practices such as over-affirmation, humour, and falsifying imitation have, therefore, been turned into a well-known pop-cultural vocabulary (see Klein 2005). Around the year 2000, computer-aided manipulations simplified the production of montages; making, assembling, and rearranging images has become a daily practice. Thus, manipulated digital images resemble their analogue predecessors. Far-right associations such as the Identitarian Movement fall back on these techniques since they intend to transform the meaning of symbols and signs (from left to right, from international to national, etc.). They make use of irony, montage, and alienation in social media. All these methods are related to the practice of détournement. Moreover, the appropriated positions that previously counted as progressive are reformulated versions for their reactionary purposes (for example, employing women's rights for xenophobic arguments).

The purpose of Identitarian "meta-politics" (the term the members use to describe their campaigns) is to produce a power shift in regard to the movement's acceptance within the predominant cultural hegemony. With their actions and campaigns, they intend to gain larger public interest and force broader media attention. Unlike the artistic avant-garde, the Identitarian Movement aims not to break with traditions but to link their ideology to a (non-existing) past by using emotionalised terms, such as nationality, tradition, or Heimat in Germany. 
The example of far-right agitation reveals that appropriation can neither be considered as innocent imitation nor harmless takeover but must be distinguished as a powerful practice. These practices are neither linked to an ideology nor to predominant relations. They require neither bottom-up principles nor do they question hegemonic relations. Edward Said's critique of "Orientalism" (1978) points to the double-edged meaning of appropriation when he explores the model of binary cultural relations. He argues that the West is using representations of the "Orient" to fulfil its desires and to affirm its power. In response to Said, the art historian Robert Nelson (1996: 127) states that

in every cultural appropriation there are those who act and those who are acted upon, and for those whose memories and cultural identities are manipulated by aesthetic, academic, economic, or political appropriations, the consequences can be disquieting or painful.

This critique demonstrates that appropriations result from the inequality of power relations, in which the adopted culture has no power over its representations. This loss of control is mirrored by the appropriation practices of the alt-right in social media, when far-right movements ensure hegemonic power relations.

\subsection{The Practice of Hoaxing as an Intervention in Cultural Grammar}

Less than twenty years before the fake-news debate became an element of public discourse, the a.f.r.i.k.a. Gruppe defined the practice of hoaxing in their manual as one that relieves the "cultural grammar" of its normative connotation (Blissett \& Brünzel 2001: 65). The term "cultural grammar," as coined by Umberto Eco, defines a cultural convention that is transported on a semiotic level by language and images. According to the communication guerrilleros, reinterpretations and liquidations of the connotations of hoaxes function to review as well as to disrupt power relations. Their use

\footnotetext{
${ }^{7}$ In the handbook of guerrilla communication, the concept of cultural grammar, with reference to Umberto Eco, is understood as a system of rules that structures social relationships and interactions (see Blissett \& Brünzel 2001: 14). This system of rules is described by Blissett and Brünzel (ibid.) as a semi-learned expression of social relations of power and domination, which seem essential for their production and reproduction.
} 
aims to confuse social consent, in order to disturb "the order of discourse" (Foucault 1971), understood as a central basis of power.

According to this manual, the aim of hoaxes is to imitate the voice of power as well as possible in order to speak in its name (and its authority) for a limited period (compare Blissett \& Brünzel 2001: 65). The media scholar Martin Doll (2012) defines this form of deception as a practical joke. As opposed to fakes, which are recognised as original, authentic, and truthful until they are accidentally unmasked, he claims that a hoax is intended to be exposed from the beginning of its production. Etymologically the term hoax refers to "hocus-pocus," a phenomenon described as "a humorous or mischievous deception, usually taking the form of fabrication of something fictitious or erroneous [...]." by uncertainties regarding their authority and factuality, which can thus be described as the goal of their political and activist use. In accord with Foucault's notion of discourse, Doll defines hoaxes as ambiguous figures which are built on the acceptance of dominant practices and orders and produced to unmask conditions of credibility, plausibility, and believability at the moment of exposure. He substantiates his analysis concerning the theorem of discourse by defining the indifference of the hoax to the field of truth. According to Foucault, this field of truth orders the truthfulness and falseness of statements at a given historical moment based on accumulations, regularities, and regulations. Doll's notion allows us to understand hoaxes as a marker of social acceptance. Regarding the academic discourse, Doll concludes that statements that are outside the field of truth are thus excluded. In contrast to Doll's theory, the fake-news debate has proven more than once that hoaxes and fakes do not necessarily aim to meet the requirements of academic discourse. Being excluded from the academic field of truth does not necessarily affect the distribution of fakes and hoaxes, nor their public confirmation. ${ }^{9}$ Hoaxes such as the Clinton collage are not aiming to alter the social discourse, in which neither deficient logic nor lack of factuality is grounds for exclusion. Therefore, I will argue that hoaxes such as the Clinton photomontage are based on popular narratives of a kind often found in myths and stereotypes.

According to Willy Viehöver (2001), these narratives represent a central characteristic of the discourse structure, which are deliberately used

\footnotetext{
${ }^{8}$ In his treatise Reflections on the Decline of Science in England, and on Some of Its Causes Charles Babbage (1989: 90) described the effect of a hoax as the "ridicule of those who credit it before it is disclosed." 9 This does not mean that there are no fakes that aim to expose the academic discourse for its own lack of authority or factuality. But it does mean that fakes are not necessarily pointing to factuality at all.
} 
to provide world views and social practices with coherence and sense, qua repetition, with a certain regularity. To this end, I propose to acknowledge the Clinton hoax as a marker of what can be said and visualised in present social discourse.

\section{/// 2. Veles, City of Deception}

In December 2016, the media service BuzzFeed reported on the North Macedonian city Veles, where about 120 fake-news blogs were then being administered (see Ladurner 2016). Since that time, Veles has been recognised as an important centre for the global production of fake news. In this former Yugoslav border town, the IFF met A., a thirty-five-year-old fakenews producer. A. and his friends had been sharing content in the form of images and texts on fake-news sites and blogs, which had already been debunked at the time. He explained to us that he shares images and texts that evoke emotions and that content-related restrictions do not exist for him. When asked about the rise of fake news, he traced it back to a general tiredness with politics in society as the result of corruption scandals. To this day, Veles has a high unemployment rate and its inhabitants live in difficult economic circumstances.

According to BuzzFeed, fake-news production in Veles during the 2016 US presidential election campaign was influenced by the Russian government (compare Silverman et al. 2018). BuzzFeed's reporting refers to the Report on the Investigation into Russian Interference in the 2016 Presidential Election - better known as the Mueller report - which proved collaboration between Russian troll factories and a marketing agency from Skopje, whose representatives wrote articles for Breitbart News (see ibid). The report says that a marketing agency from Skopje trained Veles youngsters to produce fake news. ${ }^{10}$ However, A. told us that he did not need to attend this training because his work was so easy: it only involved copying, pasting, and sharing images. A. and most of his colleagues do not write editorial contributions; they distribute "found footage" on blogs and advertise their contributions on Facebook. A. gained his income from clicks on the user-oriented advertisement that is displayed on social media and that is counted and paid for by Google Ads and Facebook. Additionally, A. made up emotionalising headlines for his picture stories to heighten the click-through rates. Digital click-working is common among young people living in Veles. A fake-news

10 Based on the Mueller report, an investigation by Wired magazine drew this connection for the first time (see Subramanian 2017). 
producer called Dimitrij, who is particularly successful, showed reporters monthly invoices amounting to more than 8,000 euros. He was not surprised by the fact that "real news" is not as effective as fake news because "they are not allowed to lie" (Jaster \& Lanius 2019: 39).

In 2016, A. switched from supporting Hillary Clinton to Donald Trump because the latter's campaign aroused more public interest and thereby a higher click-through rate. Pointing to the photomontage of Clinton (see above, Fig. 1), A. described the fakes he posted as harmless. The rasterised black-and-white print has a red frame. In the left corner, the title of the newspaper appears written in white sans-serif letters on a blackboxed background; below, the date of the issue is shown to be June 1993. To the right, there is another box with black letters that say "Space creature survived UFO crash in Arkansas." The photograph of Clinton, which probably dates to the same year, is arranged on the right side of the image. Her eyes look directly into the camera, her mouth is open. The photograph offers the impression that Clinton intends to give a statement. In her arms she holds a naked baby whose cranium is formed in a hypertrophic, hydrocephalus-like shape and who has wide-open, button-like, black eyes. The long fingers of the baby's right arm reach for Clinton's breast and point to a jagged-edged word-balloon claiming that the picture is an "official photo." On the left side, sans-serif typography fills the space with the words "Hillary Clinton adopts alien baby." Like a footnote, a caption at the bottom of the image informs us that the Secret Service is organising "a special nursery in the White House."

According to A., this image-text constellation was his most successful post at the time and therefore provided a high percentage of his income. We asked ourselves why this collage gained so much interest. To which discursive and implicit knowledge does it refer? And what is its significance within the fake-news debate? In the following section, I will analyse the role of the collage as an aesthetic and technical-medial objectivation of fake news in social media. I suggest using Foucault's theoretical notion of the dispositive representing the visible, tactile, and figurative objectification of discourses (Keller 2010: 73).

\subsection{From Tabloid Journalism to Social Media}

To fully understand the hoax's performative transmutations, appropriations, and adjustments, I will focus on its emergence. It is important to analyse the transmutations through which the hoax passed in the course of its 
distributions: in the media (from tabloid journalism to fake news) and in its technical-aesthetic aspects (from a digital collage to blogs and social-media artefacts). When A. distributed the Clinton photomontage to social media networks, it was more than thirteen years old. The tabloid Weekly World News $(W W N)$ was the first to publish the collage, on 15 June 1993. This tabloid is renowned for its cover stories on paranormal themes. In 1993, it published several articles that argued that Bill Clinton's election was endorsed by aliens. Although the paper's content is satiric, its articles follow an ideological programme which is significantly homophobic, racist, and apolitical. ${ }^{11}$ As an effect of the crisis of print journalism, today the $W W N$ is only available in the form of a blog, on which the Clinton photomontage is digitally archived. ${ }^{12}$ Due to its distribution in social media, A. links the $W W N$ programme to social media. Accordingly, it can be assumed that the tabloid's readership changed mediums as well.

The social media channels and chat rooms of the alt-right differ from analogue media not only by their different dynamics and the actualisation of their live feeds but due to their interest-led algorithms, which provide visibility and distribution. Due to this dynamic development, technical objects can be considered mere tools, since they respond poorly to social needs (compare Stiegler 2009). Moreover, the drastically changing conditions of communication and media substantially support the self-reinforcing tendencies of digital disinformation. The specific architecture of networks leads to enhancement (due to up-voting, liking, and sharing), differentiation (change in meaning, contextualisation, and commenting), and increased visibility. In doing so, that architecture can manipulate human behaviour and technical procedures, as is well reflected by the transformed use of the Clinton hoax - from a tabloid article to a social media artefact. As a result, social media artefacts follow the same strategy to gain attention as classical tabloid journalism, since the use of information, subjects, and images remains unchanged in social media: there is a reduction of complexity, a fixation on persons, emotionalisation, a tendency to reveal scandals, a preference for surprising topics, and preferential treatment of agonal structures (compare Diehl 2012; Meyer 2006: 88ff.). According to Bernhard Pörksen (2018: 75), these appropriations of tabloid media for-

\footnotetext{
${ }^{11}$ By using the term "apolitical," I point to the main thesis of Jacques Rancière, who understands political actions as a verification of equality. Accordingly, I use the term to claim that the $W W N$ 's content has an exclusionary policy.

12 "Five Classic Weekly World News Covers," Weekly World News, 2.10.2008, https://weeklyworldnews.com/headlines/3075/five-classic-weekly-world-news-covers/, accessed 30.11.2019.
} 
mats can thus be understood as a "journalistic power shift" (publizistische Machtverschiebung).

\subsection{Comet Ping Pong and Reptiloids: Conspiracy Theories as Aesthetic Appropriations and Reference Culture}

The discursive and non-discursive practices of appropriation, which are displayed on the technical and media level, become apparent in the symbolic dimension of the photomontage as well. In addition to the sans-serif typeface, to the frames and dividing lines, the digital artefact is dominated by the photograph of Clinton and the computer-simulated image of an "alien baby," which gives the impression of a serious framing. It serves to imitate an institutional character, which underpins the fake's assertion of authenticity. Both the image of Clinton and of the "alien" have media iconicity, building the fundament for the transfer of conspiratorial and ironic narratives. The imagery draws a portrait of the present world seemingly on the verge of catastrophe. On the one hand, this form of exaggeration produces ironic effects, but on the other hand the references to existing conspiracy theories are used to link the protagonists to one another (compare Bonz 2006). Hence, these references are not only markers of belonging to certain groups, but essential characteristics of the groups. Both symbols are referring - and thereby actualising - different conspiracy theories, which link specific narratives of child abuse to the conspiracy of a capitalist world supremacy, but they also similarly evoke ironic effects.

A. posted the Clinton photomontage at the same time when the "Pizzagate" conspiracy theory was widespread. The Pizzagate conspiracy originates from a bizarre piece of disinformation, according to which the Washington, DC pizzeria Comet Ping Pong served as headquarters for a child sex ring backed by Hillary Clinton. Because the Clinton hoax was satirically commenting on Clinton's role as a caring mother, it can be read as a comment on the Pizzagate conspiracy. On the one hand, the satirical exaggeration of maternal concern exposes the dissonance over Clinton's role in the Pizzagate conspiracy. On the other hand, the narratives of the collage's symbols invoke gender norms (compare Butler 1998) as they actualise patriarchal knowledge. By invoking the normative role of gender, the viewer is invited to place Clinton in a specific relationship to the cited norm and to update stereotypes as background knowledge (compare Hecken 2005). At the same time, the juxtaposition of categories such as motherhood and 
abuse creates a dichotomy between morally correct and morally wrong actions in the symbolism of the image.

Beyond Pizzagate, the image of the alien literally embodies the figure of the stranger, the intruder. The specific shape of the head and the long arms given to the baby are a reference to the conspiracy theory of the "Reptiloids," which are supposed to be partially reptilian, partially human, mixed beings, capable of taking human form. According to this theory, the elitist world supremacy consists mostly of Reptiloids. Widely disseminated during the 1990s by television shows and tabloids, this popular conspiracy theory traces back to the British ex-football professional David Icke. According to Juliane Wetzel (2005), government upheavals and the turn of the millennium affirmed various resentments that were present in society at the time, which were manifested as sexism and anti-Semitism and objectified through conspiracy theories. Icke, in his theories of pre-astronautics and criticism of the elite, linked anti-Semitic conspiracy narratives to an extra-terrestrial world-ruling class. This narrative involves a connection between politics and extra-terrestrials and is cemented in the collective memory through films such as Star Wars and Close Encounters (compare Lewis \& Kahn 2005: 4).

Furthermore, the Reptiloids conspiracy also links to abuse narratives. The conspiracy theory claims that the ruling elite of the Reptiloids, which consists of, among other people, Queen Elizabeth and Hillary and Bill Clinton, organises the molestation of children (compare Lewis \& Kahn 2005). This is a rehashed narrative, which has appeared in numerous defamatory representations since the French Revolution: then the tabloid papers printed several different depictions of the dauphine Marie-Antoinette in the shape of a harpy. These depictions appropriated both the image of a monstrous beast and its behaviour, to which the dauphine's behaviour was likened. ${ }^{13}$ Because her multinational origins inspired xenophobic prejudice, the harpy became a defamatory symbol for the dauphine, whose mere existence provoked fear and anxiety. In a stream of pamphlets and images at that time, the monarchy was condemned for its alleged monstrous incestuous-sexual appetite. Like the harpy, the figure of the alien has not completely lost its uncanny significance as an extra-terrestrial doppelganger. In entertainment formats involving uncanny conspiracy theories, the image of the alien remains a symbol of the Other, the inexplicable.

${ }^{13}$ Several depictions of harpies, of "Monstre Amphibie Vivant" linked to Marie-Antoinette can be seen in the Digital Archive of the French Revolution. See, for example, https://exhibits.stanford. edu/frenchrevolution/catalog/rf920px6566, accessed 1.03.2020. 
These similarities show that conspiracy theories, as well as photos like that of the Clinton hoax, integrate known stereotypes into ever new stories. Therefore, I claim that the conspiracy of the Reptiloids is an illustrative ideology which itself functions like a collage.

Despite its monstrous function within conspiracy theories, the symbol of the alien brings ironic effects to the image. Thus, both symbols - that of a female politician and that of an alien, whose meaning oscillates between an object of popular culture and a subject of conspiracy theories - evoke a dissonance that triggers ironic effects. Here, humorous over-affirmation and conspiracy theory flow into each other and the boundary between factual and fictional narrative is deliberately blurred, while the claim to validity is maintained. Although the dissemination of the collage contributes to the cementing of a connection between anti-Semitic and sexist political phantasms, humour is an important visual medium to keep the ideology light. Given this context, I argue that the photomontage's function is to link apocalyptic narratives and pop-cultural symbols. Its references bring well-known conspiracy narratives up to date, but the ability to encode and decode them also determines affiliation to a particular group.

\subsection{Memetics}

Due to its aesthetic and technical appropriation strategies, the Clinton photomontage has similarities to meme images, for which sans-serif fonts and tabloid contents, as well as the reinterpretation of popular symbols, are characteristic. Memes can be defined as viral cultural products that are reinterpreting popular references using the tactics of guerrilla communication (compare Goriunova 2013: 71). Andrew Breitbart, a leading methodologist of right-wing power shifts in social media, describes these shifts of signs and symbols within popular culture as grounds for a political counter-revolution (compare Ebner 2019). While situationists like Debord have aimed to destroy the discursive sphere by reinterpreting single images, memes are profiting from the network character of social media, which supports the accumulation of visibility. Other than viral artefacts, memes involve a quantity of existing parodies, mash-ups, remixes, pastiches, and re-enactments (compare Goriunova 2013: 71)..$^{14}$

${ }_{14}$ The example of the meme "Pepe the Frog" shows the different levels of memetics through which the character passed, taking not only different forms but also changing its content from leftist to rightist ideology. 
Although the Clinton hoax aesthetically and contextually refers to memes of the alt-right, it differs significantly, as A. shared the hoax again without making any changes. If the Clinton photomontage is considered a meme, it would have to be defined as one that remains at the lowest level of memetics, since it is not further developed (ibid.). On image-boards such as 4 chan and 8 chan, successful memes run through several mutations, which can be understood as evolutionary processes. ${ }^{15}$ Defining and determining their value for the alt-right through up-and-down voting, these boards are trial platforms for racist, anti-Semitic, and sexist memes, the bulk of which are used by the alt-right to undermine leftist discourse. In doing so, they accumulate visibility within the dispositive of social media.

The exhibition The Alt-Right Complex, which opened in the autumn of 2019 at the Hartware MedienKunstVerein (HMKV) in Dortmund, reflects the memetic strategies of the alt-right artistically. As memes function as seismographs of political development, Inke Arns, the director of HMKV, analysed them as strategic tools of culture wars. The exhibition showed the diverse appearances of memes but also pointed to difficulties in defining the phenomenon. So far, the appropriation policies of the alt-right cannot be explained fully, since memes as a viral phenomenon have no limitation regarding form, symbolism, and effects. Consequently, Arns understands memes as maximum provocations (compare Backof 2019). Even if they often seem to be harmless and funny, they are markers of racist, sexist, and homophobic discourse and represent the powerful alliances between despots, conspiracy theorists, and trolls.

Even though the Clinton hoax did not undergo evolutionary mutations, it can be considered a marker of the speakable/visible in political and aesthetic artefacts. Putting the Clinton hoax into the context of memes means understanding it as an active intervention in society, since its political and aesthetic function is to produce social reactions and political resonances that aim to evoke effects of subjectivation.

\subsection{The Perspective of Dispositive Analysis}

The media dispositive incorporates manipulative tools, such as hoaxes, to react to ideological crises, that is, my preceding assumption is confirmed: dispositives appropriate discourse formations, since their contained signs

\footnotetext{
154 chan and 8 chan are websites on which images can be posted anonymously. Thus, they are discussed as platforms for radicalisation, since there are no restrictions in content. Both image-boards pursue an agenda of radical free speech.
} 
assume a certain strategic function, which only becomes speakable/visible at a certain historical moment. Accordingly, the fake news from Veles did not appear accidentally but indicates a reaction to the crisis in existing power structures. Moreover, the dispositive of social media spells out the changed power relations in social discourses which are taking shape and further developing the available technical possibilities and social needs (compare Holly 2010: 155). In this sense, social media - which is, in general, a visual medium - represents, actualises, and shapes the public discourse due to the visible artefacts it contains. Virally distributed fake news mirrors the public debate and similarly strengthens its existence. The fake-news discourse organises the speakable/visible and the exclusion of the unspeakable/non-visible from the public discourse; then again, it is exactly this exclusion that links the speakable/visible implicitly back to this discourse. In this sense, conspiracy theories such as Pizzagate and the Reptiloids fall into the category of the abject (compare Kristeva 1984) due to their satirical exaltation. Therefore, the Clinton hoax functions as a reassurance of hegemonic knowledge, in which the practice of satire is used strategically to cite and to substantiate normalised and subjectivated knowledge so that it will not be forgotten. In expressing its rules by means of satirical collages, the media dispositive preserves the dispositive of sexist and anti-Semitic knowledge. Insofar as it refers implicitly to current interdictions by using the technique of satire, the Clinton hoax circumvents the prohibitions.

\section{/// 3. Conclusion}

In light of the research journey of the IFF, I have asked what role hoaxes such as the Clinton photomontage play in the fake-news debate. In contrast to other phenomena of the fake-news discourse, this collage posted by A. unmasks its epigonality on different levels. Consequently, I suggest extending the above-mentioned definition of a hoax.

The dispositive analysis shows that the hoax takes on the role of a pastiche, a collage in which various dimensions of appropriation and reinterpretation come into play. Defined as compositions, pastiches appropriate existing styles and use the work and details of other creators (here in the form of tabloid media and the aesthetics of memes). As epigonal satirical forms of deception, whose nature relies on the reinterpretation of popular references, such hoaxes are not out there for the effects that occur after their exposure. As Boris Groys (2008: 235) predicted in 2008 concerning guerrilla communication, fakes and hoaxes no longer aim to produce 
something new. Rather, these practices negotiate the struggle over the distribution of privileges and the accumulation of symbolic capital. Therefore, I have argued that the appropriation of pop-culture references is a response to Breitbart's (compare Ebner 2019) demands for aesthetic warfare not only on a symbolic level but also in terms of the references' distribution within social media.

On a symbolic level, the hoax refers not only to popular symbols but also to sexist and anti-Semitic narratives. On the one hand, the popular reference to the alien humorously highlights the extra-terrestrial as a stranger, as a doppelganger of mankind. But, on the other hand, the hoax's imagery oscillates between well-known conspiracy narratives, such as a global world conspiracy and organised child abuse. Due to the appeal to the normative reference to her social role as a woman and mother, in conjunction with the Pizzagate conspiracy, the collage also refers to sexist resentments against Hillary Clinton as a politician by means of over-identification. Contrary to the argument of Romy Jaster and David Lanius (2019), in this context I claim that these hoaxes from Veles are not solely the result of economic interest. Moreover, I would like to argue that discussing their distribution on a uniquely economic level would miss the point, since the photomontage is connected ideologically and politically to the motifs of the alt-right and exemplarily demonstrates the alt-right's guerrilla communication tactics. In this light, it becomes obvious that the line of demarcation between knowledge that is accepted and knowledge that is oppressed is not as strict as I had initially believed.

On a technical level, I have shown that the function of social media consists in appealing to and normalising sexist, racist, and hegemonic orders. The intervention in the election campaign by viral fakes such as the Clinton photomontage therefore signifies an attack on powerful categories (compare Jäger 2000). The legitimation of existing power relations and the social as well as cultural production of meaning is revealed. Here, the practice of truthful speaking is constituted, saved, or even changed (compare Foucault 1971) in reverse demarcation (e.g., in echo chambers). Thereby, the paradoxical function of the media becomes obvious: they are preserving the system as much as they undermine it. Against this background, I conclude that the dispositive of social media implements regularities and techniques that structure the fake-news discourse in a supra-individual order (e.g., due to up-and-down voting), following certain regularities and accumulations (such as in specific forums). 
Defining the Clinton photomontage as a hoax, therefore, means defining it as a materialised lie; it is an artefact that is neither what it pretends to be nor is it harmless. As I mentioned at the beginning of this chapter, hoaxes like the Clinton photomontage are dismissed as "bullshit" in the academic debate. If they do not qualify for academic debate, they may cause even more severe damage. Oscillating between popular symbols and rightwing ideology, their ambiguity points to the blind spot of the fake-news discourse: the effects of this epigonal hoax aim to blur the borders between popular culture and politics, as the preceding analyses of the discursive characteristics of the Clinton photomontage have shown. Therefore, a positivist confrontation between truth and fake news is not sufficient, as the example of the Clinton hoax proves. Epigonal hoaxes like the Clinton photomontage confront the public debate and its own limitations regarding form, symbolism, and effects. I thus conclude that the radicality of the "fake news" phenomenon consists in presenting the inadequacies of the scholarly discourse to the academic world.

In contrast to Chelsea Clinton's appraisal, my analysis proves that the collage is not a harmless hoax, but that its viral distribution contributes to the publicist power shift, since it visually appropriates sexist and antiSemite narratives in the form of satire. Moreover, the Pizzagate conspiracy, which might have seemed as harmless as the Clinton hoax, did not remain on a semiotic level. On 4 December 2016, an armed man entered the Comet Ping Pong pizza restaurant with the idea of releasing the children who were supposedly held and abused there. He shot a lock and a computer, and not having found what he expected, was arrested without protest.

Bibliography:

/// Allcott H., Gentzkow M. 2017. "Social Media and Fake News in the 2016 Election," Journal of Economic Perspectives, vol. 2, pp. 211-236, https:// doi.org/10.1257/jep.31.2.211.

/// Arendt H. 1972. Crises of the Republic: Lying in Politics; Civil Disobedience; On Violence; Thoughts on Politics and Revolution, Harvest.

/// Babbage C. 1989. Reflections on the Decline of Science in England and on Some of Its Causes, New York University Press. 
/// Backof P. 2019. "Kunstschau zur Alt-Right: 'Nicht so blauäugig durch Netz und Welt gehem,"' Deutschlandfunk, https://www.deutschlandfunk. de/kunstschau-zur-alt-right-nicht-so-blauaeugig-durch-netz-und.807.de.html?dram:article_id=445015, accessed 30.11.2019.

/// Blisset L., Brünzel S. 2001. Handbuch der Kommunikationsguerilla, Assoziation A.

/// Bonz J. 2006. "Sampling: Eine postmoderne Kulturtechnik," [in:] Kulturschutt - Über das Recycling von Theorien und Kulturen, eds. C. Jacke, E. Kimminich, S.J. Schmidt, Transcript, pp. 333-353.

/// Butler J. 1998. Haß spricht, transl. K. Menke, M. Krist, Suhrkamp.

/// Certeau M. de. 2014. Kunst des Handelns, transl. R. Voullié, Merve.

/// Chiquet V. 2018. Fake Fotos: John Heartfields Fotomontagen in populären Illustrierten, Transcript.

/// Clinton C. (@ChelseaClinton). 2017. “I'd Forgotten about My Alien Sibling from the Early 90s. Oh the Good Old Days when \#Fakenews Was about Aliens...," Twitter, 22.02.2017, https://twitter.com/ChelseaClinton/ status/834417963650392064, accessed 30.11.2019.

/// Debord G. 1984. Society of the Spectacle, transl. F. Perlman, Black \& Red.

/// Debord G. 2008. Der Beginn einer Epoche: Texte der Situationisten, transl. P. Gallissaires, H. Mittelstädt, Edition Nautilus.

/// Diehl P. 2012. "Populismus und Massenmedien," Bundeszentrale für politische Bildung, http://www.bpb.de/apuz/75854/populismus-und-massenmedien, accessed 26.09.2019.

/// Doll M. 2012. Fälschung und Fake: Zur diskurskritischen Dimension des Täuschens, Merve.

/// Ebner J. 2019. Radikalisierungsmaschinen, transl. K. Riesselmann, Suhrkamp.

/// Eco U. 1986. "Für eine semiotische Guerilla," [in:] U. Eco, Über Gott und die Welt. Essays und Glossen, transl. B. Kroeber, dtv, pp. 146-157.

/// Flatscher M., Seitz S. 2018. "Latour, Foucault und das Postfaktische: Zur Rolle und Funktion von Kritik im Zeitalter der 'Wahrheitskrise," Le foucaldien, vol. 4(1), 5, http://doi.org/10.16995/lefou.46. 
/// Foucault M. 1971. L'Ordre du discours, Gallimard.

/// Foucault M. 1980. Power/Knowledge: Selected Interviews and Other Writings, 1972-1977, ed. C. Gordon, Vintage.

/// Foucault M. 2002. "The Subject and Power," [in:] Michel Foucault: Beyond Structuralism and Hermeneutics, eds. H.L. Dreyfus, P. Rabinow, Harvester, pp. 208-226.

/// Frankfurt H. 2005. On Bullshit, Princeton University Press.

/// Frohne U., Haberer L., Urban A. 2018. "Displays und Dispositive. Ästhetische Ordnungen," [in:] Display und Dispositiv: Ästhetische Ordnungen, eds. L. Haberer, U. Frohne, A. Urban, Wilhelm Fink, pp. 5-58, https://doi.org/10.30965/9783846756348_002.

/// Goldberg R.A. 2001. Enemies Within: The Culture of Conspiracy in Modern America, Yale University Press.

/// Goriunova O. 2013. "Die Kraft der digitalen Ästhetik," Zeitschrift für Medienwissenschaft, vol. 8(1), pp. 70-87, https://doi.org/10.25969/mediarep/699.

/// Graw I. 2004. "Wo Aneignung war, soll Zueignung werden. Ansteckung, Subversion und Enteignung in der Appropriation Art," [in:] VIRUS!, eds. R. Mayer, B. Weingart, Transcript, pp. 293-312, https://doi.org/10.14361/9783839401934-014.

/// Groys B. 2008. Die Kunst des Denkens, Philo Fine Arts.

/// Hecken T. 2005. Witz als Metapher. Der Witz-Begriff in der Poetik und Literatur des 18. Jabrbunderts, Francke.

/// Holly W. 2010. "Medien, Kommunikationsformen, Textsortenfamilien," [in:] Textsorten, Handlungsmuster, Oberflächen: Linguistische Typologien der Kommunikation, ed. S. Habscheid, De Gruyter, pp. 144-163.

/// Jäger S. 2000. "Theoretische und methodische Aspekte einer kritischen Diskurs- und Dispositivanalyse," Duisburger Institut für Sprach- und Sozialforschung, http://www.diss-duisburg.de/Internetbibliothek/Artikel/ Aspekte_einer_Kritischen_Diskursanalyse.htm, accessed 22.09.2019.

/// Jameson F. 1984. "Postmodernism and Consumer Society," [in:] The Anti-Aesthetic: Essays on Postmodern Culture, ed. H. Foster, Bay Press, pp. 111-125. 
/// Jaster R., Lanius D. 2019. Die Wabrheit schafft sich ab: Wie Fake News Politik. machen, Reclam.

/// Keller R. 2010. Wissenssoziologische Diskursanalyse, VS Verlag für Sozialwissenschaften.

/// Klein N. 2005. No Logo: Taking Aim at the Brand Bullies, Knopf.

/// Kristeva J. 1984. Powers of Horror: An Essay on Abjection, Columbia University Press.

/// Ladurner U. 2016. "Fake News: Stadt der Lügner," Die Zeit, vol. 52, https://www.zeit.de/2016/52/fake-news-hersteller-unternehmen-mazedonien, accessed 22.09.2019.

/// Lewis T., Kahn R. 2005. "The Reptiloid Hypothesis: Utopian and Dystopian Representational Motifs in David Icke's Alien Conspiracy Theory," Utopian Studies, vol. 16(1), pp. 45-74.

/// Meyer T. 2006. "Populismus und Medien," [in:] Populismus: Gefahr für die Demokratie oder nützliches Korrektiv?, ed. F. Decker, VS Verlag für Sozialwissenschaften, pp. 81-96.

/// Nancy J.-L. 2010. Das Vergessen der Philosophie, Passagen.

/// Nelson R.S. 1996. "Appropriation," [in:] Critical Terms for Art History, eds. R.S. Nelson, R. Shiff, University of Chicago Press, p. 127.

/// Peters M.A. 2018. "The History and Practice of Lying in Public Life," [in:] Post-Truth, Fake News: Viral Modernity \& Higher Education, eds. S. Rider, M. Hyvönen, T. Besley, Springer, pp. 77-88.

/// Pörksen B. 2018. "Die neuen Wahrheitskriege," Zeitschrift für Medienwissenschaft, vol. 19, pp. 9-76.

/// Rancière J. 2010. Dissensus: On Politics and Aesthetics, transl. S. Corcoran, Continuum.

/// Reulecke A.-K. 2006. "Einleitung," [in:] Fälschungen: Zu Autorschaft und Beweis in Wissenschaften und Künsten, ed. A.-K. Reulecke, Suhrkamp, pp. 7-43. /// Said E.W. 1978. Orientalism, Pantheon.

/// Schober A. 2005. "Ästhetik des Politischen," Österreichische Zeitschrift für Geschichtswissenschaften, vol. 15(3), pp. 5-6.

/// Schober A. 2009. Ironie, Montage, Verfremdung, Wilhelm Fink. 
/// Silverman C., Feder J.L., Cvetkovska S., Belford A. 2018. "Macedonia's Pro-Trump Fake News Industry Had American Links and Is under Investigation for Possible Russia Ties," BuzzFeed News, https://www. buzzfeednews.com/article/craigsilverman/american-conservatives-fake. news-macedonia-paris-wade-libert, accessed 30.10.2019.

/// Stehr N. 1994. Arbeit, Eigentum und Wissen: Zur Theorie von Wissensgesellschaften, Suhrkamp.

/// Stiegler B. 2009. Technik und Zeit, transl. G. Ricke, R. Voullié, Diaphanes. /// Subramanian S. 2017. "Inside the Macedonian Fake-News Complex," Wired, 15.02.2017, https://www.wired.com/2017/02/veles-macedoniafake-news, accessed 30.10.2019.

/// Uscinski J.E. 2017. "The Election Was Rigged, the News Is Fake, and the Deep State Is Out to Get Us," Eurozine, https://www.eurozine.com/ the-election-was-rigged-the-news-is-fake-and-the-deep-state-is-out-to-getus/, accessed 1.09.2018.

/// van Dyk S. 2017. “Krise Der Faktizität?”, PROKLA. Zeitschrift Für Kritische Sozialwissenschaft, vol. 47(188), pp. 347-368.

/// Viehöver W. 2001. "Diskurse als Narrationen," [in:] Handbuch Sozialwissenschaftliche Diskursanalyse: Band I: Theorien und Methoden, eds. R. Keller, A. Hirseland, W. Schneider, W. Viehöver, VS Verlag für Sozialwissenschaften, pp. 177-206.

/// Wetzel J. 2005. “Die 'Protokolle der Weisen von Zion' im World Wide Web. Die Vernetzung radikaler politischer Gruppen über antisemitische Verschwörungstheorien," Jabrbuch für Antisemitismusforscbung, vol. 14, pp. 179-194.

/// Willmann T. 2004. “The Truth Is a Threat,” Telepolis, https://www.heise. $\mathrm{de} / \mathrm{tp} /$ features/The-truth-is-a-threat-3524606.html, accessed 27.10.2019. 


\section{/// Abstract}

In February 2016, the Institute for Falsification researched the production of fake news in Veles, North Macedonia. Focusing on a specific hoax distributed from Veles via social media, this article analyses the political and aesthetic effects of fake news. It argues that fakes and hoaxes (mis)use established references to renew pre-existing discourses, media techniques, and symbols. The present definition of fakes is therefore insufficient for these practices.

Keywords:

aesthetics, fakes, hoaxes, journalism, memes, social media dispositive

/// Thari Jungen - PhD candidate in the "Performing Citizenship" graduate programme in Hamburg, Germany. Her artist-based research focuses on fakes and hoaxes as phenomena of performing citizenship. She studied architecture and media art, sculpture and performance at Hochschule der Bildenden Künste Saar (HBKsaar) in Saarbrücken and at the Weissensee Academy of the Arts in Berlin. Her recent artistic production Show Me Your Agenda was shown in May 2017 at K3/Kampnagel in Hamburg. She is the author (with Paula Hildebrandt) of "Menschen, Tiere, Sensationen" in Zeitschrift der Dramaturgischen Gesellschaft (2016); "Re(Labelling): Mimicry between Subjectivation and Identification" in Performing Citizenship (2019); and the forthcoming "Collaborative Authorship - Or How to Overcome the "Nightmare of Participation"" in Constructions of Media Authorship. She is also the founder of the artistic research collaborative Institute for Falsification.

ORCID: https://orcid.org/0000-0003-3361-9777

E-mail: thari.jungen@gmail.com 